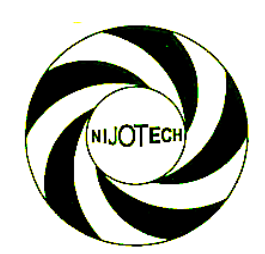

Nigerian Journal of Technology (NIJOTECH)

Vol. 38, No. 2, April 2019, pp. 355 - 363

Copyright@ Faculty of Engineering, University of Nigeria, Nsukka

Print ISSN: 0331-8443, Electronic ISSN: 2467-8821 www.nijotech.com

http://dx.doi.org/10.4314/njt.v38i2.12

\title{
PHYSIOCHEMICAL PROPERTIES OF MIXED TWIN CLAY DEPOSITS IN AWGBU USED FOR POTTERY AND POSSIBLE STRUCTURAL APPLICATIONS
}

\author{
O. Kalu ${ }^{1,}{ }^{*}$, A. N. Amah' ${ }^{2}$ and I. M. Echi ${ }^{3}$ \\ 1, Dept. Of Physics, Material Science Division, Federal University, Lafia, NASARAWA State, NIGERIA

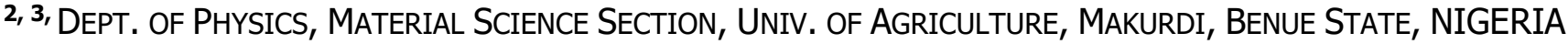 \\ E-mail addresses. ${ }^{1}$ konyekachi@gmail.com, ${ }^{2}$ odunnze@gmail.com, 3 idugbae@gmail.com
}

\begin{abstract}
The practice of mixing Asha clay and Ajagworo clay deposit at Ngene-Agu site in the ratio of 3:1 by Awgbu women for pottery business is investigated. Physical (Atterberg limits) properties, elemental content, compressive strength, water absorption and characterization for individual and mixed clays were carried out. The result obtained shows that between $700{ }^{\circ} \mathrm{C}$ and $1100{ }^{\circ} \mathrm{C}$, the compressive strength of Asha clay and Ajagworo clay derived burnt bricks did not individually meet the Nigeria specifications for structural development, while that of the mixed clay derived burnt bricks satisfied the minimum strength requirement of $2 \cdot 50 \mathrm{~N} / \mathrm{mm}^{2}$ at $1000^{\circ} \mathrm{C}$ and above. The result also showed that the mixed clay derived burnt bricks has the least values for porosity of $0 \cdot 568$ and water absorption at varying temperatures. This has proved that the practice by Awgbu women of mixing Asha and Ajagworo in the ratio of 3:1 raised the compressive strength to $3 \cdot 81 \mathrm{~N} / \mathrm{mm}^{2}$ and lowered the water absorption to a minimum value of $12 \cdot 2 \%$. This work has shown that the Awgbu mixed clay can be used for structural development in Anambara State and Nigeria.
\end{abstract}

Keywords: Awgbu mixed clay, Compressive strength, Water Absorption, Porosity and Structural development.

\section{INTRODUCTION}

One of the oldest and artificial building material for housing is the clay bricks [1], which are widely used because of their low cost, easy availability, good compressive strength, fire resistance, weather resistance, good sound and thermal insulation properties. In addition, their durability and aesthetic appeal contribute to its extensive application in both load bearing and non-load bearing structures with ease during construction [2]. Clays are products of intense chemical weathering of different rock types. The characteristics and properties of the resulting clay depend on the physiochemical factors dominating the environment of their formation [3].

In some part of Nigeria, traditional housing units are made of locally produced burnt bricks which can be produced on large scale and at a very cheaper rate than sandcrete blocks. Pottery business is also known to be a source of income for the rural women where clay deposits exist [4-6]. For structural development, bricks are classified mainly by both the average or minimum compressive strength and the percentage water absorption [7-9]. According to this classification, required minimum compressive strength of bricks is $2.5 \mathrm{~N} / \mathrm{mm}^{2}$, while the water absorption should not exceed $20 \%$. However, some bricks fall short of these specifications either because of inherent properties or method of production.

Over the past fifteen years, the presence of mineral admixtures in construction materials has been observed to impart significant improvement on the strength, durability and workability of cementitious products [9-14]. For instance, Agbede and Joel [10] reported that the compressive strength and water absorption of burnt clay bricks attained a maximum value of $18.64 \mathrm{~N} / \mathrm{mm}^{2}$ and a minimum value of 14.8 $\%$ respectively at $2 \%$ additive of rice husk ash (RHA) whose oxides of calcium and silicate improved the

\footnotetext{
* Corresponding author tel: + 234-806-939- 7775
} 
inter particle bonding of the soil particles with better properties of the bricks [15].

In Benue State, North Central Nigeria, the floodplain soil deposits along the banks of major rivers and seasonal streams are sources of raw materials for the production of local burnt bricks for the construction of houses. This is evident from the obtained water absorption of $3-4 \%$, ignition loss of $31-36 \%$ and compressive strength of between $38-111 \mathrm{~N} / \mathrm{mm}^{2}$ for Benue clays [16]. These parameters satisfy the requirements specified by relevant Nigerian Standards for burnt bricks [17] of which the minimum compressive strength of bricks for a building is 2.5 $\mathrm{N} / \mathrm{mm}^{2}$ with dimension $277 \mathrm{~mm} \times 100 \mathrm{~mm} \times 66 \mathrm{~mm}$ [18].

The firing technique for burnt bricks requires the arrangement of the sun-dried bricks in tubular or pyramid-shaped heaps provided with several interconnected tunnels to allow for circulation of air and heat. The tunnels are then stuffed with dry wood which is the source of fuel and fire until the natural grey colour of the bricks turns red. Eighty percent $(80 \%)$ of modern structures such as residential houses for family standard of three to four-bedroom bungalow in the state capital Makurdi have been constructed with these locally made burnt bricks at a cost savings of much as $30 \%$ as an alternative to cement blocks $[19,20]$.

The aesthetic nature of these structures requires no rendering and such houses constructed in the 1950s still stand the test of the time. These houses are reported to be cooler and more comfortable compared to the cement block equivalent because brick is a poor conductor of heat. The walls of the houses are also fire resistant because of high temperature firing during production. Figures $1 a$ and $1 b$ shows a three bedroom bungalows constructed with the locally manufactured burnt bricks in Makurdi, one without rendering showing the aesthetic nature of the structure.

Awgbu town is in Orumba North Local Government Area of Anambra State, South East of Nigeria is located at latitude $6^{\circ} 07^{\prime} \mathrm{N}$ and longitude $7^{\circ} 06^{\prime} \mathrm{E}$. The town has two types of clay deposits at Ngene - Agu site called Asha (ASH) and Ajagworo (AJA). The business of pottery making by Awgbu women is as old as Awgbu and flourished well until the late 1980s when lighter plastic containers took over. The method of preparing the clay and firing of the pots for pottery production is similar to the preparation and production of burnt clay bricks in Makurdi, however, the Ajagworo clay is used as an additive to Asha in the ratio of $1: 3$ by the Awgbu women. This research investigates the effect of Ajagworo as an additive to Asha on the properties of the clay at varying temperatures. The result will also suggest the possible use of Awgbu clays for massive structural development in Anambra State.

\section{MATERIALS AND METHODS}

\subsection{Materials}

Twenty (20) $\mathrm{kg}$ each of Asha(ASH) and Ajagworo (AJA) clay sample from Awgbu town in Orumba North Local Government Area of Anambra State, located on latitude $6^{\circ} 0.7 \mathrm{~min}$ North and longitude $7^{\circ} 0.6 \mathrm{~min}$ in South East of Nigeria were dugged and collected using a digger and hoe respectively.
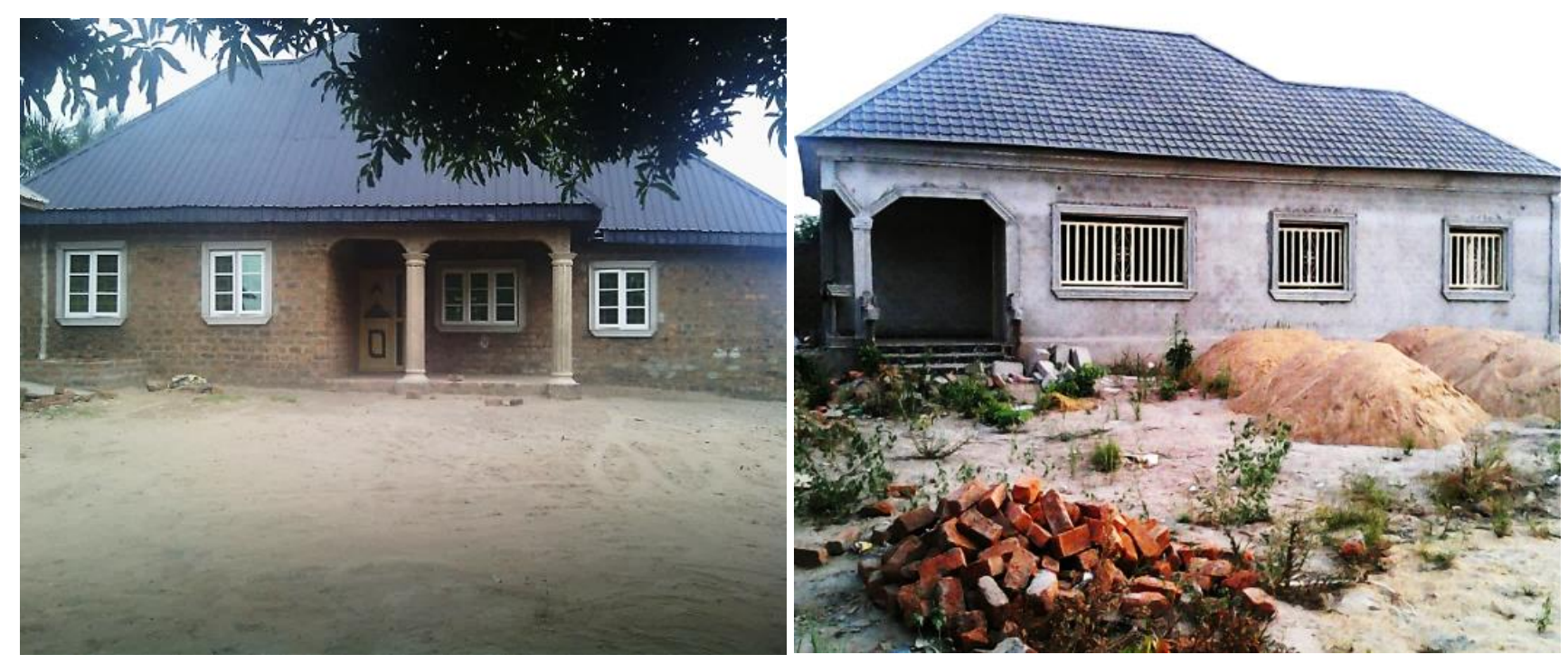

Figure 1: Three bedroom bungalows constructed with Makurdi local burnt bricks (a) without rendering; (b) with rendering 
Other materials include the ASTM sieve number 40 ( $0.425 \mathrm{~mm}$ mesh diameter), the cast mold $(150 \mathrm{~mm} \times$ $90 \mathrm{~mm} \times 80 \mathrm{~mm}$ ) and the Energy Dispersive X-ray Fluorescence Machine.

\subsection{Methodology}

About $8 \mathrm{~kg}$ each of Asha (ASH) and Ajagworo (AJA) clays obtained from Ngene - Agu site at the depths of $15 \mathrm{~cm}$ to $30 \mathrm{~cm}$. Root remains and other materials were removed by sieving through ASTM sieve number $40(0.425 \mathrm{~mm}$ mesh diameter). About $3 \mathrm{~kg}$ of the ASH clay and AJA clay mixture in the ratio $3: 1$ was obtained. The mixture of Asha and Ajagworo was tagged AASJ.

Particle size distributions, Atterberg limits, linear shrinkages and relative densities were determined for $\mathrm{ASH}, \mathrm{AJA}$, and AASJ respectively according to the standard procedures [21, 22]. Afterwards the soils were separately mixed thoroughly with water to a uniform consistency followed by molding of the bricks using a cast iron mold of $150 \mathrm{~mm} \times 90 \mathrm{~mm} \times 80 \mathrm{~mm}$ dimensions and subsequently compressed locally using the wooden plank. The molded bricks were extruded by loosening the mold and carefully removing the bricks and left to dry for 14 days before analysis. The chemical composition of the elemental contents of the three categories of the clay soils at a raw state and at the three firing temperatures $\left(700^{\circ} \mathrm{C}\right.$, $1000^{\circ} \mathrm{C}$ and $1100^{\circ} \mathrm{C}$ ) were determined and measured from X-ray Fluorescence spectra analysis. The compressive strengths, cold water absorptions, bulk density and porosity test of the bricks were equally determined.

\subsection{Compressive Strength}

The result of the compressive test was performed with a maximum of 300 tones compressing testing machine at a progressive constant loading rate of $50 \mathrm{~N} / \mathrm{s}$. The load in Newton $(\mathrm{N})$ at which the burnt bricks failed were noted and the maximum compressive strength (CS) for each sample of the brick was calculated using the relation as:

$$
\mathrm{CS}=\frac{\mathrm{MLF}}{\text { contact area }} \quad \mathrm{N} / \mathrm{mm}^{2}
$$

Where MLF is the maximum load at failure

\subsection{Water of Absorption}

The percentage of cold water adsorption test for Awgbu clay samples was carried out after 24 hours and the obtained results are being recorded. The adsorption of a material can be described as the increase in weight of a material due to moisture in the air. Three (3) samples of the burnt bricks with their considered ratios were weighed individually and recorded as $M_{1}$, followed by immersion into the water for 24 hours and subsequently weighed as $M_{2}$ which is determined by the equation 2.0

Water of absorption $=\frac{M_{2}-M_{1}}{M_{1}} \times 100 \%$

$M_{1}$ represents the weight of dried bricks before immersion while $M_{2}$ is the weight of bricks after 24 hours of immersion.

\subsection{Porosity Test}

The porosity test which is dependent on the bulk density, particle density and the porosity inclusive were obtained for the burnt bricks both at a raw state and fired state respectively. The durability of the burnt brick which is dependent on the bulk density (BD) has an influence on strength and water absorption, where the bulk density obtained for the bricks are given by the relation as:

$$
B D=\frac{\text { mass of the brick }}{\text { dimensional volume of brick }}\left(\frac{\mathrm{kg}}{\mathrm{m}^{3}}\right)
$$

The porosity of the brick sample was determined by immersing the bricks in a water bath maintained at $95 \pm 5^{\circ} \mathrm{C}$ and left for 24 hours after which the raw and fired bricks were removed in order to determine and record the masses of the brick samples before and after immersion using the equation 4.0

$$
\text { Porosity }=\frac{M_{1}-M_{2}}{\rho V} \times 100 \%
$$

Where $M_{1}$ weight of dried bricks before immersion, $M_{2}$ weight of bricks after 24 hours of immersion, $\rho$ is the density of water and the $V$ volume of the brick samples

\section{RESULTS AND DISCUSSION}

\subsection{Physical Properties}

The results presented in Fig. 2 represent the particle distributions of ASH, AJA, and AASJ respectively. The particle sizes distributions showed $40 \%$ clay, $25 \%$ silt, and $35 \%$ sand for each of the clay samples.

The content of sand from the particle size distribution for all the samples are of fine grains. The clay content of above $30 \%$ indicate the samples are suitable for clay burnt bricks [23]. However, Asha (ASH) showed finer clay and silt particles content than Ajagworo 
Physiochemical Properties of Mixed twin Clay Deposits in Awgbu Used for Pottery and Possible ..., o. Kalu, et al

$(A J A)$ which can be attributed to the high amount of finer particle with high inter-particle packing.

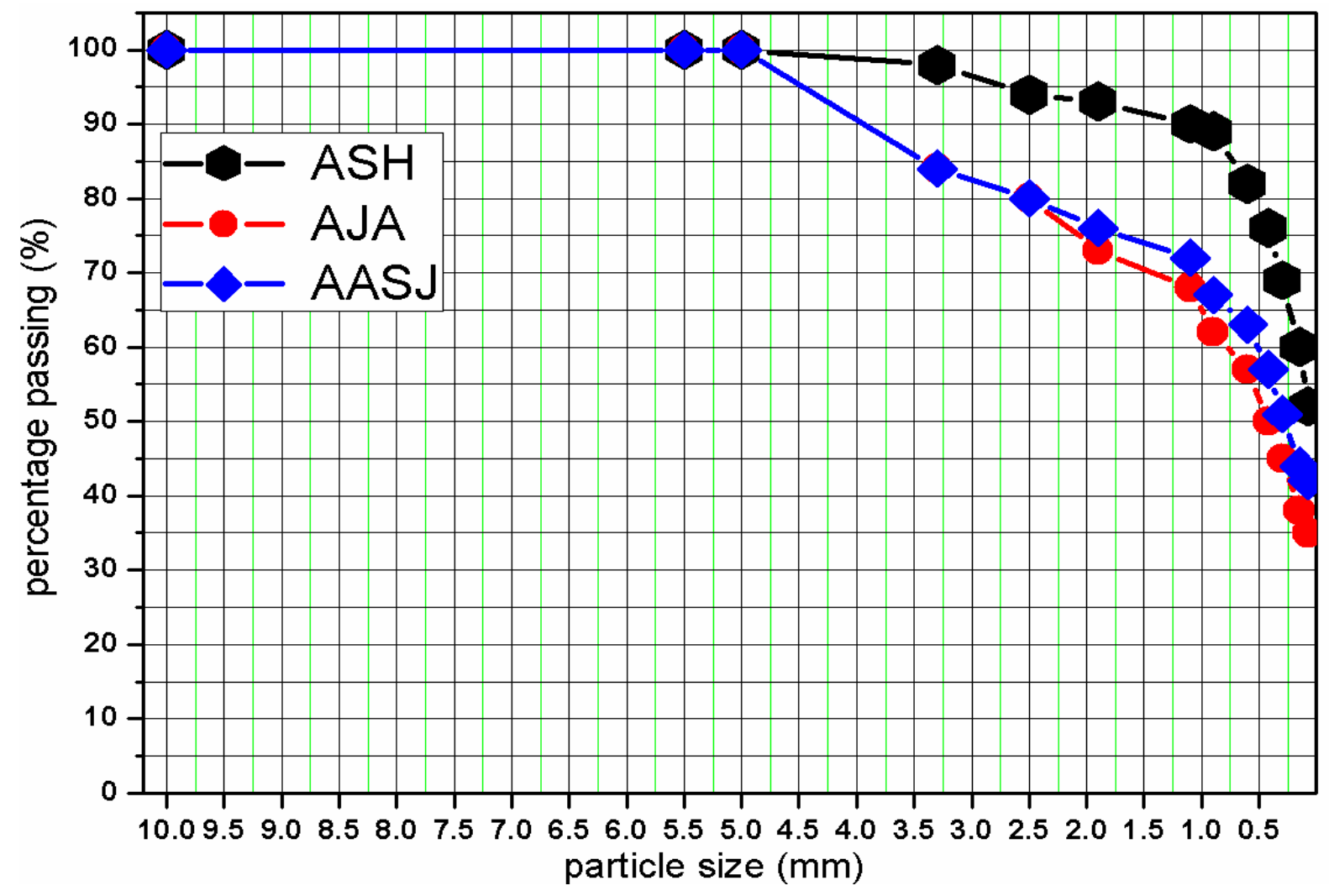

Figure 2: Particle distribution of Asha (ASH) Ajagworo (AJA) and Mixed (AASJ) clay

Table 1: Physical properties of the clays

\begin{tabular}{lccc}
\hline \multirow{2}{*}{ PROPERTY } & \multicolumn{3}{c}{ CLAY SAMPLES } \\
\cline { 2 - 4 } & ASH & AJA & AASJ \\
\hline Liquid limit (\%) & $50 \cdot 0$ & $48 \cdot 0$ & $32 \cdot 7$ \\
Plastic limit (\%) & $22 \cdot 6$ & $37 \cdot 5$ & $13 \cdot 5$ \\
Plasticity index (\%) & $27 \cdot 4$ & $10 \cdot 5$ & $19 \cdot 2$ \\
Linear Shrinkage (\%) & $8 \cdot 6$ & $12 \cdot 1$ & $15 \cdot 0$ \\
Specific gravity & $2 \cdot 64$ & $2 \cdot 25$ & $2 \cdot 45$ \\
\hline
\end{tabular}

The Atterberg's limits of each sample which represents the physical properties of the samples under investigation are shown in Table 1. From the values in Table 1, it is evident that the addition of $A J A$ to $A S H$ led to decrease in silt and clay fractions in $A A S J$ sample by forming a coarser material with a larger surface area which requires more water. This condition still favours good compaction due to the high fraction of $40 \%$ clay and $35 \%$ sand content with finer particles which is traceable to the values of the liquid limit and plastic limit of $32.7 \%$ and $13.5 \%$ respectively for AASJ sample as a clay-sand-silty soil sample. The plasticity index which varied from $10.5 \%$ to $27.4 \%$ with AASJ sample at about $19 \%$ (medium plasticity index) indicates particle size distribution of clay above $30 \%$ with improved plasticity and densification of the soil [24].

The increase in linear shrinkage from $8.6 \%$ to $15 \%$ for $A A S J$ sample which may be troublesome can be attributed to the coarse texture from the addition of AJA into the ASH sample, however the value falls within the range of $4 \%$ to $25 \%$ maximum [25] since the medium plasticity index value of $19 \%$ for AASJ sample implies the ratio of 3:1 will help with shrinkage problem at low volume changes from the bricks manufactured using these soil [26]. The reduction in the specific gravity from 2.64 to 2.45 may be the consequence of the admixture of AJA to ASH sample which is connected to the effect of organic matter in the collected samples. However, the specific gravity value of 2.45 for AASJ sample is slightly lower compared to the normal range of 2.55 to 2.88 [27] may be associated with the compaction nature of the AASJ sample.

\subsection{Element Composition Analysis from XRF}

In the XRF measurement both for the raw and fired samples, three predominant oxides namely $\mathrm{Al}_{2} \mathrm{O}_{3}, \mathrm{~S}_{i} \mathrm{O}_{3}$, and $\mathrm{Fe}_{2} \mathrm{O}_{3}$ were detected as shown in Table 2. The effect of firing temperatures with respect to the oxides 
from the elemental content on the three clay soil types was investigated.

It was noticed that each clay sample contained 13 oxides of elements except for AJA sample, where $\mathrm{Na}^{2} \mathrm{O}$ surfaced at $1000{ }^{\circ} \mathrm{C}$ and $1100^{\circ} \mathrm{C}$. The three predominant oxides in the order $\mathrm{S}_{\mathrm{i}} \mathrm{O}_{3}>\mathrm{Al}_{2} \mathrm{O}_{3}>\mathrm{Fe}_{2} \mathrm{O}_{3}$, constitute $95 \%$ of the entire content while the remaining ten oxides account for the remaining $5 \%$. At higher temperatures, the reactions between $\mathrm{S}_{i} \mathrm{O}_{3}$ and $\mathrm{Al}_{2} \mathrm{O}_{3}$ results in the formation of kaolin, a cementitious substance responsible for the strength of the bricks [10]. However, the percentage contents of $\mathrm{Al}_{2} \mathrm{O}_{3}$ and $\mathrm{S}_{3} \mathrm{O}_{3}$ were directly and inversely proportional to increase in firing temperature for AASJ sample. Report from literature confirms that $\mathrm{MgO}, \mathrm{CaO}, \mathrm{Na}_{2} \mathrm{O}$, and $\mathrm{K}_{2} \mathrm{O}$ at fired temperatures reduce refractoriness of bricks, however, Silica $\left(\mathrm{S}_{\mathrm{i}} \mathrm{O}_{3}\right)$ also reduces refractoriness and crushing strengths of the bricks [22]. This explains the improved compressive strength from $2.50 \mathrm{~N} / \mathrm{mm}^{2}$ to $3.81 \mathrm{~N} / \mathrm{mm}^{2}$ of the mixed clay (AASJ) at higher temperatures of $1000^{\circ} \mathrm{C}$ and $1100^{\circ} \mathrm{C}$ due to complicated chemical reaction which forms a silicate of the respective oxides with very small progressive decrease in $\mathrm{S}_{i} \mathrm{O}_{3}, \mathrm{MgO}, \mathrm{CaO}$ and $\mathrm{Na}_{2} \mathrm{O}$ in Table 2.

Furthermore, variation in the colour alteration of the bricks are shown in Table 3. The brick samples respectively were fired respectively from $700^{\circ} \mathrm{C}$ to $1100^{\circ} \mathrm{C}$ with no indication of crack, however the colour changed from cream to pink and finally brown with increase in firing temperature. These implies the variation of percentage content of $\mathrm{Fe}_{2} \mathrm{O}_{3}$ at different temperature and the brown colour signified the oxidation of iron III $\left(\mathrm{Fe}_{2} \mathrm{O}_{3}\right)$ into iron II $\left(\mathrm{FeO}_{4}\right)$ at higher temperatures which induce colour changes and reduces fusion temperature in bricks.

The recorded results from the compressive strength of the fired bricks from $700{ }^{\circ} \mathrm{C}, 1000^{\circ} \mathrm{C}$ and finally 1100 ${ }^{\circ} \mathrm{C}$ generally increased with increase in firing temperatures. The obtained values which varied from $0.94 \mathrm{~N} / \mathrm{mm}^{2}$ to $1.73 \mathrm{~N} / \mathrm{mm}^{2}, 0.83 \mathrm{~N} / \mathrm{mm}^{2}$ to 2.42 $\mathrm{N} / \mathrm{mm}^{2}$ and $1.70 \mathrm{~N} / \mathrm{mm}^{2}$ to $3.81 \mathrm{~N} / \mathrm{mm}^{2}$ for ASH, AJA and AASJ samples respectively could be due to the mineral content of the soil. The resulting improved compressive strength of the burnt bricks may be linked to the chemical reaction and vitrification process when subjected to higher temperatures [28]. For the mixed clay which is the (AASJ) sample, the compressive strength obtained at the different firing temperatures were $1.70 \mathrm{~N} / \mathrm{mm}^{2}, 2.50 \mathrm{~N} / \mathrm{mm}^{2}$ and $3.81 \mathrm{~N} / \mathrm{mm}^{2}$ as shown in Fig. 3 are within the British Standard (BS: 1976) specification of $2.75 \mathrm{~N} / \mathrm{mm}^{2}$ and $1.38 \mathrm{~N} / \mathrm{mm}^{2}$ for bricks use for two storey buildings and non -load bearing walls respectively. Therefore, this range is within the accepted Nigerian standard for burnt bricks at a minimum compressive strength of $2.50 \mathrm{~N} / \mathrm{mm}^{2}$ [17].

Table 2: Elemental contents of the ASH, AJA and AAJS clays from room to fired temperatures

\begin{tabular}{|c|c|c|c|c|c|c|c|c|c|c|c|c|}
\hline \multirow{2}{*}{$\begin{array}{c}\text { Oxides } \\
\text { of } \\
\text { elements } \\
(\mathrm{w} \%)\end{array}$} & \multicolumn{4}{|c|}{$\mathrm{ASH}$} & \multicolumn{4}{|c|}{ AJA } & \multicolumn{4}{|c|}{ AASJ } \\
\hline & Raw & $700^{\circ} \mathrm{C}$ & $1000^{\circ} \mathrm{C}$ & $1100^{\circ} \mathrm{C}$ & Raw & $700^{\circ} \mathrm{C}$ & $1000^{\circ} \mathrm{C}$ & $1100^{\circ} \mathrm{C}$ & Raw & $700^{\circ} \mathrm{C}$ & $1000^{\circ} \mathrm{C}$ & $1100^{\circ} \mathrm{C}$ \\
\hline $\mathrm{Na}_{2} \mathrm{O}$ & 0.000 & 0.0000 & 0.000 & 0.000 & 0000 & 0.0000 & 0.114 & 0.042 & 0.000 & 0.000 & 0.000 & 0.000 \\
\hline $\mathrm{MgO}$ & 0.718 & 1.337 & 1.120 & 0.816 & 584 & 5.958 & 6.046 & 6.111 & 2.5 & 2.407 & 2.135 & 1.845 \\
\hline $\mathrm{Al}_{2} \mathrm{O}_{3}$ & 18.900 & 28.793 & 25.670 & 24.495 & 16.510 & 17.772 & 18.010 & 19.473 & 24.352 & 23.855 & 24.774 & 26.064 \\
\hline $\mathrm{SiO}_{3}$ & 55.416 & 54.670 & 55.440 & 56.608 & 61.609 & 61.980 & 61.325 & 59.798 & 58.860 & 58.170 & 57.441 & 56.333 \\
\hline $\mathrm{SO}_{3}$ & 0.418 & 0.301 & 0.338 & 0.340 & 0.409 & 0.526 & 0.538 & 0.546 & 0.297 & 0.298 & 0.321 & 0.332 \\
\hline $\mathrm{Cl}$ & 0.011 & 0.016 & 0.020 & 0.023 & 0.029 & 0.028 & 0.076 & 0.095 & 0.011 & 0.030 & 0.013 & 0.010 \\
\hline $\mathrm{K}_{2} \mathrm{O}$ & 0.735 & 0.502 & 0.574 & 0.622 & 0.749 & 0.710 & 0.705 & 0.702 & 0.566 & 0.564 & 0.568 & 0.5470 \\
\hline $\mathrm{CaO}$ & 0.191 & 0.145 & 0.165 & 0.169 & 0.880 & 0.822 & 0.841 & 0.852 & 0.303 & 0.326 & 0.314 & 0.312 \\
\hline $\mathrm{TiO}_{2}$ & & 1.924 & & & 1950 & 1.828 & & & & 2.087 & 2.173 & 2.195 \\
\hline $\mathrm{Cr}_{2} \mathrm{O}_{3}$ & 0.06 & 0.034 & 0.0 & 0.0 & 0.032 & 0.0269 & 0.0 & 0. & 0.029 & 0.032 & 0.033 & 0.033 \\
\hline $\mathrm{Mn}_{2} \mathrm{O}_{3}$ & 0.057 & 0.035 & 0.039 & 0.041 & 0.269 & 0.309 & 0.252 & 0.239 & 0.106 & 0.113 & 0.125 & 0.132 \\
\hline $\mathrm{Fe}_{2} \mathrm{O}_{3}$ & 20.455 & 12.221 & 14.359 & 14.365 & 11.926 & 9.996 & 10.251 & 10.479 & 10.884 & 12.097 & 12.063 & 12.096 \\
\hline $\mathrm{ZnO}$ & & 0.0009 & 0.011 & 0.0 & 0.028 & 0.025 & 0.021 & & 0.008 & 0.009 & 0.011 & 0.012 \\
\hline SrO & 0.031 & 0.013 & 0.016 & 0.014 & 0.026 & 0.019 & 0.019 & 0.019 & 0.013 & 0.011 & 0.017 & 0.020 \\
\hline
\end{tabular}

Table 3: Colour variation at different firing temperatures

\begin{tabular}{ccccc}
\hline Sample & Raw & $700^{\circ} \mathrm{C}$ & $1000^{\circ} \mathrm{C}$ & $1100^{\circ} \mathrm{C}$ \\
\hline ASH & Ash & Cream & Pink & Brown \\
AJA & Grey & Cream & Pink & Brown
\end{tabular}




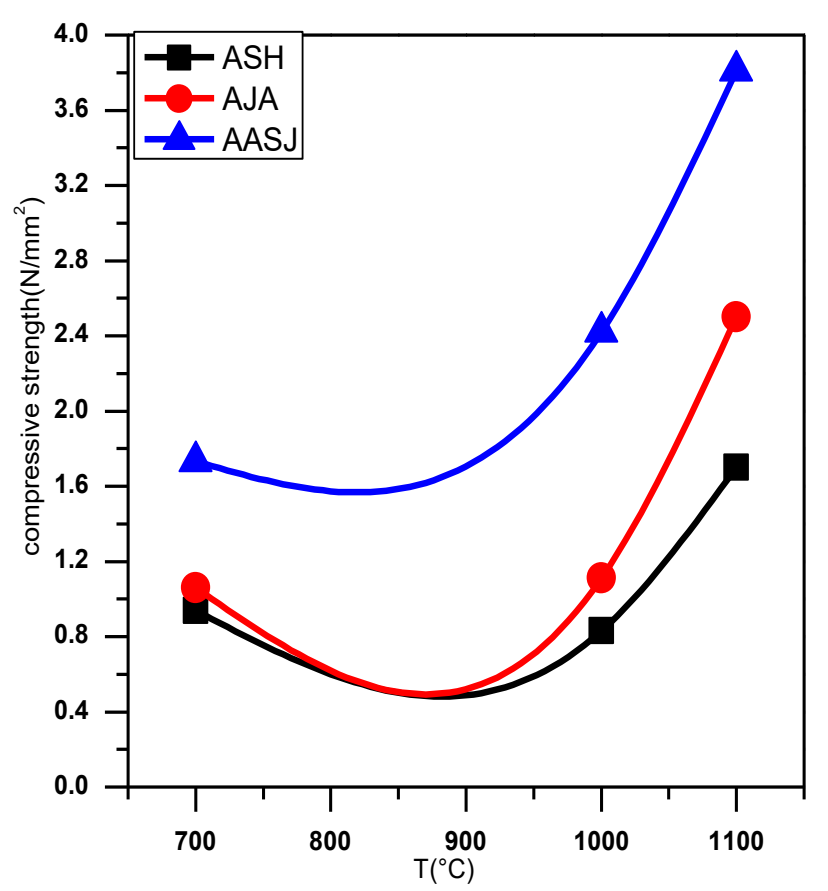

Figure 3: Effect of firing temperature on the compressive strength of brick samples

Table 4: Coldwater absorption of $A S H, A J A$, and AASJ at different firing temperatures

\begin{tabular}{llll}
\hline Sample & $700^{\circ} \mathrm{C}$ & $1000^{\circ} \mathrm{C}$ & $1100{ }^{\circ} \mathrm{C}$ \\
\hline ASH & 20.60 & 18.20 & 17.40 \\
AJA & 20.90 & 17.80 & 14.60 \\
AASJ & 16.50 & 14.80 & 12.20 \\
\hline
\end{tabular}

Generally, all the brunt bricks produce from the clay samples showed a remarkable decrease in water

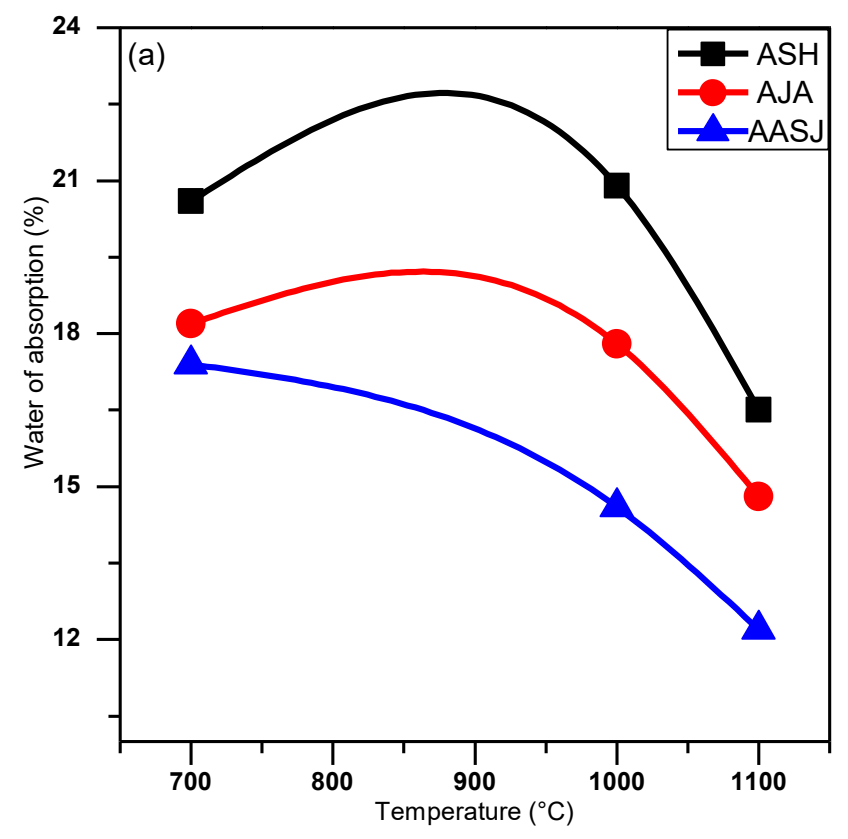

Nigerian Journal of Technology absorption at the firing temperature of $700{ }^{\circ} \mathrm{C}, 1000$ ${ }^{\circ} \mathrm{C}$ and $1100{ }^{\circ} \mathrm{C}$ as shown in Fig. 4a. The decrease in water of absorption could be associated with the soil sample and the manufacturing process. For instance, during extrusion process manufactured bricks are denser with smaller voids hence absorbs less water. The obtained water absorption values reduced from $20.60 \%$ to $17.40 \%, 20.90 \%$ to $14.60 \%$, and 16.50 $\%$ to $12.20 \%$, for ASH, AJA and AASJ clay burnt brick respectively as the firing temperature increased. The cold water absorption test for Awgbu clay gave minimum value of $12.2 \%$ for the burnt brick from AASJ sample which is within the limit less than $20 \%$ by weight for building with burnt bricks as the acceptable standard for burnt bricks production [29]. Also, the formation of a glassy phase which begins at about $900^{\circ} \mathrm{C}$ could be attributed to decrease in pores sizes and water absorption of the burnt bricks [30, 31].

The water of absorption for the burnt bricks in Fig. $4 \mathrm{~b}$ revealed that the ASSJ sample had the lowest percentage of water absorption summation of about $43.5 \%$ compared to the other samples. This validates the description of its plasticity index at $19 \%$ as "medium plasticity" due to the addition of AJA as an addictive to ASH sample which improved the drying strength of the AASJ clay with reduced problem of fabrication, drying and shrinkage of the manufactured brick $[25,32]$

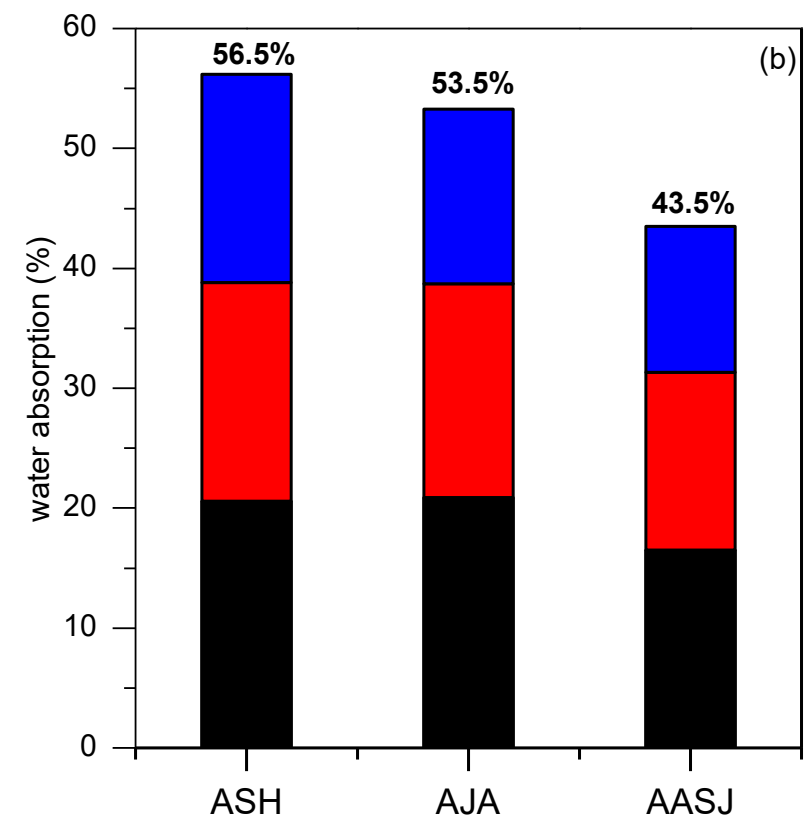

Vol. 38, No. 2, April 2019 
Figure 4: (a) Effect of firing temperature on water absorption and (b) summation of water of absorption for ASH, AJA and AASJ burnt bricks at vary temperatures
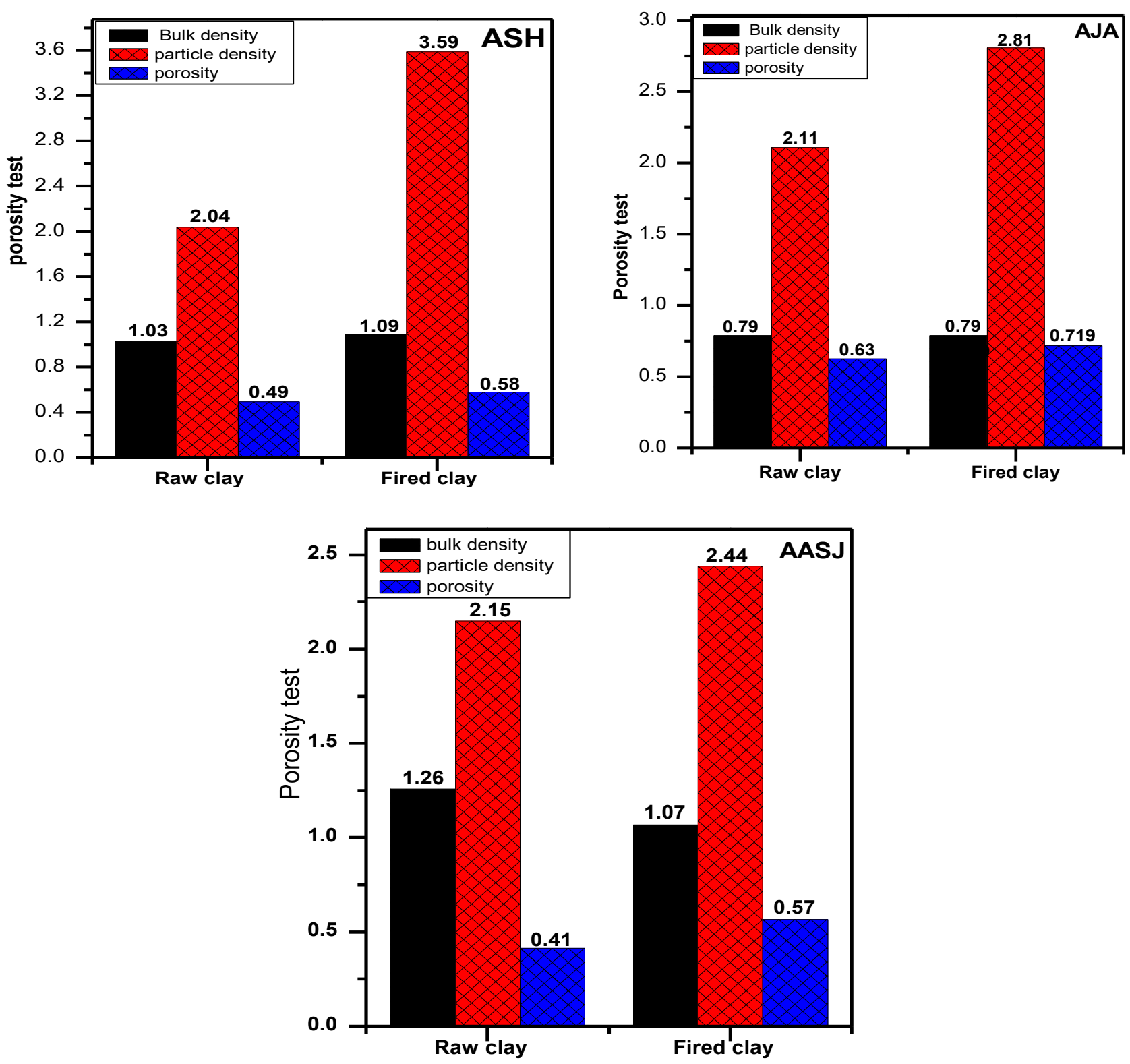

Figure 5: Summary on bulk density, particle density and porosity (a) ASH, (b) AJA, (c) AASJ at a raw state and fired state of $11000^{\circ} \mathrm{C}$.

For the raw state of the burnt bricks, an increase in bulk density was noticed from $1.03 \mathrm{~kg} / \mathrm{m}^{3}$ to $1.26 \mathrm{~kg} / \mathrm{m}^{3}$ in Fig. 5(a-c). This indicates increase in strength and decrease water absorption upon addition of AJA sample as an addictive to ASH sample which reduces the pore size, with high inter particle packing of the ASSJ sample, hence an indicator desirable for brick quality [33, 34]. However, for the fired clay samples an opposite trend was observed with a slight decrease for AASJ sample from $1.09 \mathrm{~kg} / \mathrm{m}^{3}$ to $1.07 \mathrm{~kg} / \mathrm{m}^{3}$. This may be associated with the addition of AJA sample whose bulk density value is constant for both the raw and fired state as an additive, lack of good compactness in the process of forming which may have created voids in the bricks extruded thereby reducing the bulk density and the thermal transformation into other phases when subjected to heating as a function of contact with impurities, microbes and chemicals [35]. Although the decrease in water absorption value which ensures a decrease in pore sizes indicates a good quality brick for AAS] sample and its possible application to structural development.

The particle density for both raw and fired clay sample increased and decrease for ASH, AJA and AASJ sample respectively. The value from the raw state samples 
increased from $2.04 \mathrm{~kg} / \mathrm{m}^{3}$ to $2.15 \mathrm{~kg} / \mathrm{m}^{3}$ for AASJ sample which may be connected to the larger pore size after the addition of AJA which reduce the finer clay and silt particle of the ASH sample, however the fired clay value decreased from $3.59 \mathrm{~kg} / \mathrm{m}^{3}$ to $2.44 \mathrm{~kg} / \mathrm{m}^{3}$ . The decrease in particle density may be the presence of organic matter which burnt off during the firing process and the decrease shows a potential use of the fired clay bricks as light -weight building materials [36] The percentage porosity for the raw and fired samples indicated that AASJ had the lowest values of 0.414 and 0.568 percent respectively as shown in Fig. $5(\mathrm{a}-\mathrm{c})$. The decrease in porosity may be linked to the organic matter content which increase vitrification and subsequently the closure of smaller pores with enhanced atomic bonding between particles by solid state diffusion that reduced porosity within the microstructures [37]. This suggests that the reduction in porosity which is below the 0.51 and 0.58 specification of the Institute of Science and Technology for ceramics and bricks respectively [2] enhanced and increased the compressive strength which minimized the intrusion of water since high porosity value encourages high water absorption which is not desirable in terms of durability and quality of bricks [31].

\section{CONCLUSION}

This work has confirmed that bricks for building can be produced by mixing the Agbwu clay samples at an appropriate ratio. Asha clay and Ajagworo clay separately did not meet the minimum compressive strength of $2.5 \mathrm{~N} / \mathrm{mm}^{2}$ of the Nigerian standard owing to their high porosity values of 0.58 and 0.72 respectively. The water of absorption values for all samples also falls within the stipulated limit of less the $20 \%$ for brick production, but with the addition of an addictive the ASSJ samples became stabilized with a minimum value of $12 \%$ with an improved compressive strength of $3.81 \mathrm{~N} / \mathrm{mm}^{2}$. Therefore, the practice by Awgbu women of mixing Asha clay and Ajagworo clay in the ratio 3: 1 has proved not to be a futile effort because this has raised the compressive strength and lowered the water absorption to the accepted standard for burnt bricks in Nigeria. This work has also shown that the Awgbu mixed clay can be used for structural development in Anambra state just like what is going on in Makurdi, Benue State.

\section{REFERENCES}

[1] Hendry, A. W. Reinforced and Pre-stressed Concrete. Longman Scientific and Technical. John Wiley and Sons, New York, 1991.

[2] Akankpo, A. O., Stephen, J.O. "Investigation on the physical properties of Uruan clay soil used for manufacturing of burnt bricks", Advances in physics theories and application, Vol. 53, 2224719x, 2016.

[3] Ushie, F. A., Anike, O. L. "Utilization of Lateritic Clays for Burnt Bricks and other Earthenwares in Obudu Area, S. S. Nigeria", Scientia Africana, 9(2), $59-67,2010$.

[4] Edem, E. P., "Implication of early Pottery Practice by Women in Nigeria: A Focus on women pottery practice in Akwa-Ibiom State" International journal of Scientific and Research Publications, Vol.69, 2016, 760-764.

[5] Okpoko, A. I., "Pottery making in Igboland, Eastern Nigeria, An Ethno archaeological study" Proceedings of Prehistoric society, 53, 445-455, 1987.

[6] Chukwu, G. Igbo Women and Economic Transformation in Southeastern Nigeria, 19001960, Routledge, New York, 2005.

[7] BDS - Brick Development Association, Bricks, Their Properties, and Use. Construction Press Limited, 1974.

[8] IS 1077, Indian Standard: Common Burnt Clay Building Bricks - Specification. $5^{\text {th }}$ Edition. BIS: New Delhi, 1992.

[9] Ibanga, E. J., Ahmed, A. D. "Influence of Particle Size and Firing Temperature on Burnt Properties of Rice/Clay Mix", Pacific Journal of Science and Technology. 8(2), $267-271,2007$.

[10] Agbede, I. O., Joel, M. "Effect of Rice Husk Ash (RHA) on the Properties of Ibaji Burnt Clay Bricks", American Journal of Scientific and Industrial Research. 2(4), 674 - 677, 2011.

[11] Oyekan, G. L., and Kamiyo, O. M. "A solution on the Engineering Properties of Sandcrete Blocks produced with Rice Husk Ash blended Cement", Journal of Engineering and Technology Research, Vol. 3(3), Pp. 88 - 98, 2011.

[12] Falade, F. "The use of Ground Broken Bottles as Partial Replacement of Cement in Concrete", Proceedings of Fourth International Conference on Structural Engineering Analysis and Modelling, Ghana, pp. 473 - 486, 1997.

[13] Mental, P. Q., "Mineral Admixtures for Concrete An Overview of Recent Developments. In: Advances in Cement and Concrete. Proceedings of Engineering Foundation Conference", 
Physiochemical Properties of Mixed Twin Clay Deposits in Awgbu Used for Pottery and Possible ..., O. Kalu, et al

University of New Hampshire, Durham, Pp. 243 256.1994.

[14] Okongwu, D. A. "Effect of Additive on the Burnt Properties of Clay Bricks" Ceramic Bulletin, 67(8), 1409 - 1411, 1988.

[15] Sutas, J., Mana, A., Pitak, L. "Effect of Rice Husk and Rice Husk Ash to properties of Bricks", Procedia Engineering, 32, 1061-1067, 2012.

[16] Tse, A. C. "Suitability of Flood Plain Deposits for the Production of Burnt Bricks in Parts of Benue State, Central Nigeria", Geoscience, 2(2), 1 - 6 . DOI: 10.5923/j.geo.20120202.01, 2012.

[17] Nigeria Standard Organization: Nigerian Institute of Standards (NIS). Specification for Burnt clay building units, 74, UDC 624 0128, 1976.

[18] Digyhan, N. N.: Characterization of Clay deposits from Kaura Namoda (Yankaba), Zamfara State, Nigeria. M.Sc. Thesis, Department of Physics University of Agriculture, Makurdi. Benue State, Nigerian 2014.

[19] Mesida, E. A. "Utilisation of some lateritic clays for burnt bricks", Journal of Mining and Geology, Vol. 15,2, 108-114, 1978.

[20] Rahma, M. A. "Properties of clay-sand-rice-husk ash mixed bricks", International Journal of Cement Composites and Light weight concrete, 9, 2, 105-108,1987.

[21] British Standards Institute (BSI): British Standard Methods of Test for Soils for Civil Engineering Purposes. BS 1377; Part 2, p.61, 1990.

[22] Amah, A. N., and Kur, A. "Chemophysical Characterization of Clay Soil used for locally manufactured Burnt Bricks in Makurdi, Benue State, Nigeria", Journal of Engineering and Applied Sciences. Vol. 7, No. 1 and 2, pp. $93-$ 95; 2011.

[23] Sowers, G. B., Sowers, G. F. Introductory Soil Mechanics and Foundation. Geotechnical Engineering, 4th Edition Macmillan, New York, 1979.

[24] Negedu, A. M., Nwakonobi, T. U., "Evaluation of Properties of Makurdi Laterite-clay Rice-husk Ash Bricks for pavements", Civil and Environmental research, 7, 11, 2015,

[25] Fromme, R., "Basic Notes on Clays and Clay bodies. In: Glaze and Clay Tutorial 2". http://Cator.hsc.edu/ kmd/ cavenman/projects/ pottery/basic clay.html.Retrieved ,October, 23, 2018.
[26] Orts M. J. Escardino A. Amoro's J. L. Negre, F. "Microstructural changes during firing of stoneware floor tiles", Applied Clay Science, 8, p.193-205, 1993

[27] Bowels, J. E., Physical and Geotechnical properties of soils, Mc Graw-Hill, New York, 1979.

[28] Tsega, E., Mosisa, A. Fufa, F. "Effect of firing time and temperature on Physical Properties of fired clay bricks", America Journal of Civil Engineering, 5, 1, 2017, 21-26.

[29] Rajput, R. K. Engineering Materilas, S. Chand and Company Limited, New Delhi, Indian, 2006.

[30] Cultrone G. Sebastián E. Elert K. de la Torre M. J. Cazalla O. Rodriguez-Navarro C., "Influence of mineralogy and firing temperature on the porosity of bricks", Journal of the European. Ceramic Society, 24, p.547-564, 2004.

[31] Adjei, H. D.: Durability of locally produced burnt bricks, M.Sc. Thesis, Department of Materials Engineering, Kwame Nkrumah University of Science and Technology, Ghana, 2014.

[32] Lakho, N. A., Zardari, M. A., "Structural properties of Baked clay bricks fired with alternative Fuels" Engineering, 8, 676-683, 2016.

[33] Nwobodo C. S. Davies T. J. "The effect of apparent porosity on the modulus of rupture of alumina-chromia refractory matrix", $A$ Paper Presented at FUTO 2000, Annual Conference of NAMMES., p.8, 2000.

[34] Weng C. H., Lin D. F., Chiang P. C. "Utilization of sludge as brick materials", Advance. Environment Research, 7, p.697-685, 2003.

[35] Lee S, King, K. J., Lee, H. L, Moon, H. S., "Electron-Beam-Induced phase transformations from Metakaolinite to Mullite Investigated by EF-TEM and HRTEM", Journal of America. Ceramics. Society, 84, p. 2096-2099, 2001.

[36] Kadir, A. A., Mohajerani, A., "Physical and Mechanical properties of fired clay bricks incorporated with cigarette butts. Comparison between slow and fast heating rates" Applied Mechanics and Materials, 421, 201-204, 2013.

[37] Kim, J., Dong, H. Seabaugh, J. Newell, S.W., Elbert, D. D., "Role of Microbes in the smectiteto-Illite reaction", Science, 303, p. 830-832, 2004. 